\title{
Tame thoughts on violence
}

Melvin Konner

Aggression: Conflict in Animals and Humans Reconsidered. By John Klama. Longman, Harlow, UK/Wiley, New York:1988. Pp.169. Hbk \$17.95; pbk £6.95.

BY THE time I got to the last page, I had racked my brains for hours trying to figure out why this book had been written. Turning back to the first lines of the preface, I found a possible clue: its genesis, reportedly, was in "the relaxed sun-and-wine ambience" of a conference in the south of France in the summer of 1980. Evidently the potent blend of photic and bibulous stimulation had so dazed the authors that they persuaded themselves that the world needed another critique of biological theories of aggression.

In the years leading up to their Provençal idyll, Ashley Montagu had published a one-sided but competent review of the case against innate aggression, Marshall Sahlins had led an anthropological assault against sociobiology, and somewhere between scores and hundreds of reviews had critically assessed books by Konrad Lorenz, E.O. Wilson, Richard Dawkins and others who had attempted to explore the intrinsic forces that might contribute to violence.

The present authors - John Durant, a zoologist at the Department for External Studies at the University of Oxford, Peter Klopfer, a zoologist at Duke University, and Susan Oyama, a psychologist at the John Jay College of Criminal Justice, City University of New York - pressed on undaunted. More critiques of behavioural biology appeared in rapid succession, threatening to scoop them. Not In Our Genes, by Stephen Rose, Richard Lewontin and Leon Kamin emerged in 1984. It was, like the work at hand, grotesquely biased and misleading, but at least it had some substance; it gave the earnest reviewer something to get hold of.

In 1985 Philip Kitcher published the first good (although still very biased) book criticizing sociobiology. This impressive scholarly work also failed to deflect Durant, Klopfer and Oyama from their goal: to summarize the 1980 conference and the subsequent thoughts provoked by it. They list six other authors - Erika Honore, Lisa Klopfer, Martha Klopfer, Tamara Kohn, Bryan Lessley and Nadav Nur - all of whom contributed to an unpublished volume. This the three main authors rewrote, "in order to achieve an integrity that many separate writers cannot achieve". But, oddly, they did not put their own names on the cover, preferring the invented name, John Klama. The passing years did not prevent the work from eventually coming to light in 1988; this may constitute a record for long-term effects of a brief exposure to the environment of the south of France.

The book is a 155-page whirlwind tour through the most visible part of the ethology and sociobiology of human and animal aggression, and of human nature more generally. It consists mainly of tiny treatments - usually in two- or threepage bites - criticizing major and minor works on these subjects. With apparent ease the complex observations of Charles Darwin, Sigmund Freud, Konrad Lorenz, Paul MacLean, E.O. Wilson, Richard Dawkins, Jose Delgado, Robert Axelrod and other contributors to this debate, large and small (including, alas, myself), are disposed of. The treatments have a depth of insight and freshness worthy of examination essays ("Compare and contrast the theories of innate aggression put forth by three of the following five scientists ..."). Textbook examples of environmental influences on behaviour round out the familiar picture. There is not a single new fact, idea, analysis or synthesis that might move forward, even a bit, the frontier of knowledge about this grave human and scientific problem, on which the world's future may hinge; only breezy criticisms of the best efforts of others.

The scientist interested in aggression, selfishness or the idea of human nature has little to gain from this book. As for the hapless general reader, for whom it was apparently intended, even an average introductory psychology textbook has more to offer in clarifying these matters, and much else besides. Respected opponents of sociobiology! Surely you can do better than this!

Perhaps we can now solve the Klama dilemma. My guess would be that the authors read the galleys early this year, after the dazzling effect of the famed sun of Provence had finally worn off. They forebore to place their own names on the document (at this point, who could blame them?) and they had a truly creative thought: to fix the blame on the pseudonymous, eponymous John Klama!

Bad luck for a fellow who had only just been brought into existence, and who'd had no say in the matter whatsoever. I think the poor man ought to raise a Klama about it - that is, if he can find an aggressive impulse somewhere in his mythical (mystical?) hormones, experience or (perish the possibility) genes.

Melvin Konner is Samuel Candler Dobbs Professor of Anthropology and an Associate Professor of Psychiatry at Emory University, Atlanta, Georgia 30322, USA.

\section{Celestial eccentric}

\section{Simon Schaffer}

The Peripatetic Astronomer: The Life of Charles Piazzi Smyth. By H. A. Brück and M. T. Brück. Adam Hilger: 1988. Pp. 274. $£ 29.50, \$ 80$.

ONE of the few unsurprising features of the life of the superb Victorian eccentric, Charles Piazzi Smyth, was his choice of career as a professional astronomer. Born in 1819 into the family of the naval officer William Smyth, whose Cycle of Celestial Objects (1844) became a bible for Victorian amateur observers, Charles in addition had as godfather the great Sicilian astronomer Giuseppe Piazzi.

With his father's aid, the 16-year-old Piazzi Smyth became assistant to Thomas Maclear at the Cape of Good Hope, and met John Herschel, then doyen of British astronomy. The decade in South Africa formed Smyth's future concerns. He won the patronage he needed to get the post of Astronomer Royal for Scotland, which he held from 1846 until 1888. Maclear, a precision astronomer, worried about his

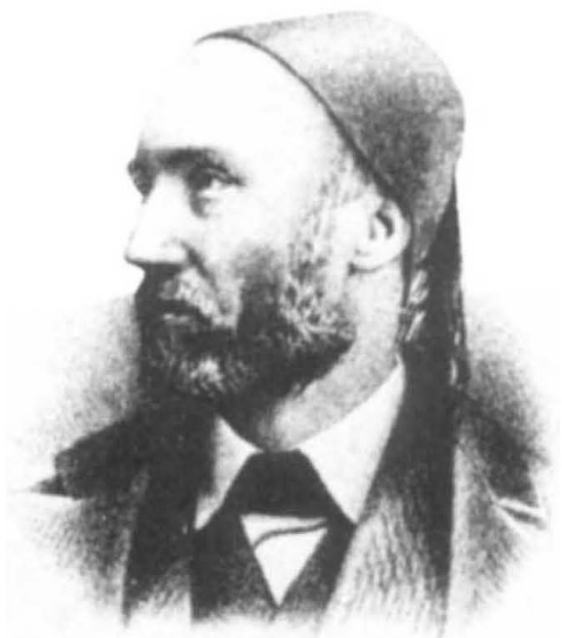

Simyth - respected but troubling gadfly.

youthful assistant's interest in the optical properties of comets' tails, while Herschel aided Smyth's devotion to photography. Smyth's pictures of the Cape observatory, the authors of this welcome study suggest, may be the earliest photographs of an astronomical establishment.

The Edinburgh Observatory atop Calton Hill became Smyth's base. While conscientiously completing the pro- 